\title{
Latitudinal variation in virus-induced mortality of phytoplankton across the North Atlantic Ocean
}

\author{
Kristina DA Mojica ${ }^{1}$, Jef Huisman ${ }^{2}$, Steven W Wilhelm ${ }^{3}$ and Corina PD Brussaard ${ }^{1,2}$ \\ ${ }^{1}$ Department of Biological Oceanography, Royal Netherlands Institute for Sea Research (NIOZ), Texel, \\ The Netherlands; ${ }^{2}$ Department of Aquatic Microbiology, Institute for Biodiversity and Ecosystem Dynamics \\ (IBED), University of Amsterdam, Amsterdam, The Netherlands and ${ }^{3}$ Department of Microbiology, University \\ of Tennessee, Knoxville, TN, USA
}

\begin{abstract}
Viral lysis of phytoplankton constrains marine primary production, food web dynamics and biogeochemical cycles in the ocean. Yet, little is known about the biogeographical distribution of viral lysis rates across the global ocean. To address this, we investigated phytoplankton groupspecific viral lysis rates along a latitudinal gradient within the North Atlantic Ocean. The data show large-scale distribution patterns of different virus groups across the North Atlantic that are associated with the biogeographical distributions of their potential microbial hosts. Average virusmediated lysis rates of the picocyanobacteria Prochlorococcus and Synechococcus were lower than those of the picoeukaryotic and nanoeukaryotic phytoplankton (that is, $\mathbf{0 . 1 4}$ per day compared with 0.19 and 0.23 per day, respectively). Total phytoplankton mortality (virus plus grazer-mediated) was comparable to the gross growth rate, demonstrating high turnover rates of phytoplankton populations. Virus-induced mortality was an important loss process at low and mid latitudes, whereas phytoplankton mortality was dominated by microzooplankton grazing at higher latitudes $\left(>56^{\circ} \mathrm{N}\right)$. This shift from a viral-lysis-dominated to a grazing-dominated phytoplankton community was associated with a decrease in temperature and salinity, and the decrease in viral lysis rates was also associated with increased vertical mixing at higher latitudes. Ocean-climate models predict that surface warming will lead to an expansion of the stratified and oligotrophic regions of the world's oceans. Our findings suggest that these future shifts in the regional climate of the ocean surface layer are likely to increase the contribution of viral lysis to phytoplankton mortality in the higher-latitude waters of the North Atlantic, which may potentially reduce transfer of matter and energy up the food chain and thus affect the capacity of the northern North Atlantic to act as a long-term sink for $\mathrm{CO}_{2}$. The ISME Journal (2016) 10, 500-513; doi:10.1038/ismej.2015.130; published online 11 August 2015
\end{abstract}

\section{Introduction}

Viruses are important mortality agents for marine phytoplankton (Evans et al., 2003; Tomaru et al., 2004; Brussaard, 2004a; Baudoux et al., 2006). Through the lysis of their autotrophic hosts, viruses regulate primary production (Suttle et al., 1990) and have key roles in species competition and succession of phytoplankton populations (Gobler et al., 1997; Mühling et al., 2005; Haaber and Middelboe, 2009). Moreover, lysis of microbes diverts energy and biomass away from the classical grazer-mediated food web toward microbial-mediated recycling and the dissolved organic matter pool. This 'viral shunt' reduces the transfer of carbon and nutrients to higher trophic levels, while enhancing the recycling of potential growth-limiting nutrients (Fuhrman, 1999;

Correspondence: KDA Mojica, Department of Biological Oceanography, Royal Netherlands Institute for Sea Research (NIOZ), PO Box 59, 1790 AB, Texel 1790 AB, The Netherlands.

E-mail: kristina.mojica@nioz.nl

Received 10 November 2014; revised 7 June 2015; accepted 18 June 2015; published online 11 August 2015
Wilhelm and Suttle, 1999). In this manner, viruses have major effects on nutrient cycles and energy flow in the ocean (Brussaard and Martinez, 2008; Weitz and Wilhelm, 2012). As microbial photoautotrophs are responsible for roughly half of the global annual carbon dioxide fixation and sustain the higher trophic levels in marine ecosystems (Field et al., 1998), their viruses also have the potential to influence these global scale processes.

Marine virus dynamics and virus-host interactions are affected by both abiotic and biotic factors (Mojica and Brussaard, 2014), which can vary on both spatial and temporal scales. However, despite biogeographical distributions of bacteria and phytoplankton being extensively studied (Irigoien et al., 2004; Martiny et al., 2006; Fuhrman et al., 2008), the possible existence of biogeographical patterns in marine viral populations (and how these may vary) has received less attention (Breitbart and Rohwer, 2005; Angly et al., 2006; Matteson et al., 2013). For example, thermal stratification is an important factor regulating phytoplankton dynamics and oceanclimate models predict that global warming will 
lead to an expansion of the stratified regions of the world's oceans (Sarmiento et al., 1998; Toggweiler and Russell, 2008). Projected alterations to stratification and vertical mixing have the potential to affect the species composition (Huisman et al., 2004; Mojica et al., 2015), phenology (Edwards and Richardson, 2004), productivity (Gregg et al., 2003; Behrenfeld et al., 2006; Polovina et al., 2008), size structure (Daufresne et al., 2009; Hilligsøe et al., 2011), nutritional value (Mitra and Flynn, 2005; Van de Waal et al., 2010), abundance (Richardson and Schoeman, 2004) and biogeographical distribution (Doney et al., 2012; Flombaum et al., 2013; van de Poll et al., 2013) of marine phytoplankton. As obligate parasites, viruses rely on their host to provide the machinery, energy and resources required for viral replication and assembly. Consequently, factors regulating the physiology, production and removal of the host are also important in governing viral dynamics (Van Etten et al., 1983; Moebus, 1996; Baudoux and Brussaard, 2008; Maat et al., 2014). Therefore, future changes in stratification also have the potential to affect the composition and distribution of viral assemblages associated with phytoplankton communities, and the sensitivity of marine phytoplankton populations to grazing and viral infection.

The North Atlantic Ocean offers a large-scale latitudinal gradient, with permanent stratification in the subtropics and seasonal stratification in the temperate zones (Longhurst, 2007; Jurado et al., 2012). The spring phytoplankton bloom is triggered by reduced vertical mixing and the onset of seasonal stratification, owing to warming of the surface waters (Sverdrup, 1953; Huisman et al., 1999; Taylor and Ferrari, 2011), and represents one of the most important biological events in the North Atlantic (Siegel et al., 2002). The bloom begins in DecemberJanuary at a latitude of $\sim 35^{\circ} \mathrm{N}$, just north of the permanently stratified waters of the North Atlantic Subtropical Gyre and subsequently spreads across the North Atlantic throughout spring and summer, expanding northward to the Arctic waters in June (Siegel et al., 2002). The spring bloom takes up large amounts of $\mathrm{CO}_{2}$, and owing to deep water formation at high latitudes the North Atlantic has a key role in oceanic $\mathrm{CO}_{2}$ sequestration (Deser and Blackmon, 1993). Yet, little is known about the biogeographical patterns in viral abundances and viral lysis rates of phytoplankton across the North Atlantic, and how these may affect the transfer of the photosynthetically acquired carbon and energy to higher trophic levels. This is primarily because of a severe lack of quantitative estimates of phytoplankton losses due to viral lysis (Weitz and Wilhelm, 2012) and how these relate to changes in environmental variables.

In this study, we therefore investigate large-scale distribution patterns of the following: (i) marine viral groups and their potential hosts, and (ii) viral lysis and grazing rates of marine phytoplankton over a latitudinal gradient across the North Atlantic Ocean.
Specifically, we assess the following hypotheses:

(H1) the abundances and composition of the microbial host populations (that is, bacteria and phytoplankton) vary with latitude (H1a) and are strongly affected by changes in water column stratification (H1b). (H2) The biogeographical distributions of the different viruses depend on the biogeographical distributions of their microbial host populations. (H3) Viral lysis rates of marine phytoplankton vary with latitude, affecting the relative importance of the viral shunt versus the classic grazing-mediated food web.

\section{Materials and methods}

\section{Sampling and physicochemical variables}

In July-August of 2009, 32 stations were sampled in the Northeast Atlantic Ocean during the shipboard expedition of STRATIPHYT (changes in vertical stratification and its impacts on phytoplankton communities) (Figure 1). Water samples were collected from at least 10 separate depths in the top 250-m water column using GO-flow (General Oceanics, Miami, FL, USA), 10-liter samplers mounted on an ultra-clean (trace-metal free) system equipped with CTD (Sea-Bird Electronics, Bellevue, WA, USA) with standard sensors and auxiliary sensors for chlorophyll autofluorescence (Chelsea Awuatracka MK III sensor, Chelsea Instruments, West Molesey, UK). Data from the chlorophyll autofluorescence sensor were calibrated against high-performance liquid chromatography data according to van de Poll et al. (2013), in order to determine the total chlorophyll $a$ (Chl a). Samples were taken inside a $6-\mathrm{m}$ clean lab for analysis of inorganic nutrients $(5 \mathrm{ml})$ and flow cytometry $(10 \mathrm{ml})$. Samples for dissolved inorganic nutrients $(5 \mathrm{ml})$ were analyzed onboard using a Bran +Luebbe Quaatro AutoAnalyzer (SEAL Analytical $\mathrm{GmbH}$, Norderstedt, Germany) for dissolved orthophosphate (Murphy and Riley, 1962), nitrate and nitrite $\left(\mathrm{NO}_{x}\right)$ (Grasshoff, 1983), and ammonium (Koroleff, 1969; Helder and de Vries, 1979). Detection limits were $0.028 \mu \mathrm{moll}^{-1}$ for $\mathrm{PO}_{4}^{3-}, 0.10 \mu \mathrm{mol} \mathrm{l}^{-1}$ for $\mathrm{NO}_{x}$ and $0.09 \mu \mathrm{mol} \mathrm{l}^{-1}$ for $\mathrm{NH}_{4}^{+}$. Water samples for the modified dilution assay, to determine viral lysis and microzooplankton grazing rates on phytoplankton, were taken from the depth with maximal phytoplankton Chl $a$ autofluorescence, that is, the deep chlorophyll maximum (DCM) or mixed layer (ML). All materials used for sampling water for dilution experiments were prewashed in acid ( $0.1 \mathrm{M} \mathrm{HCl}$, overnight), rinsed with Milli-Q water (Veolia Water Technologies, Ede, Netherlands) (three times) and rinsed with in-situ water before use.

Density of seawater was expressed as $\sigma_{\mathrm{T}}$ values, defined as $\sigma_{\mathrm{T}}=\rho(S, T)-1000$, where $\rho(S, T)$ is the density of seawater at temperature $T$ and salinity $S$ measured in $\mathrm{kg} \mathrm{m}^{-3}$ at standard atmospheric pressure. Temperature eddy diffusivity $\left(K_{\mathrm{T}}\right)$ data, referred to here as the vertical mixing coefficient, were 


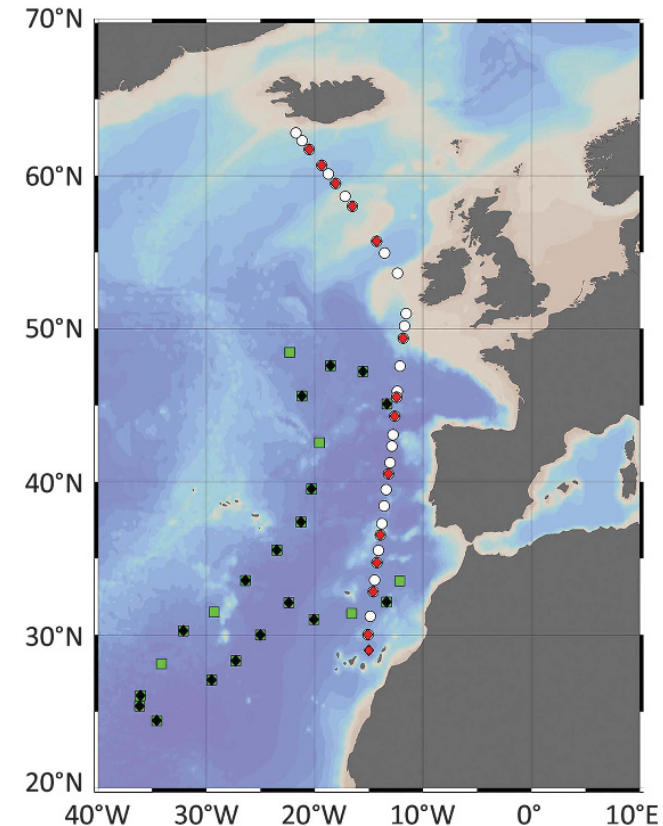

Figure 1 Bathymetric map of the stations sampled during the cruises STRATIPHYT (white circles and red diamonds) and MEDEA (green squares and black diamonds). Modified dilution assays to determine viral lysis and microzooplankton grazing rates were performed at stations indicated by the red and black diamonds. Cruise track was prepared using Ocean Data View (ODV version 4.6.5, Schlitzer, 2002).

derived from temperature and conductivity microstructure profiles measured using a SCAMP (Self Contained Autonomous Microprofiler) (Stevens et al., 1999; Jurado et al., 2012). The SCAMP was deployed at fewer stations (that is, 14) and to lower depths (up to $100 \mathrm{~m}$ ) than the remainder of the data in the present study. In order to correct for this deficiency, data were interpolated using the spatial kriging function 'krig' executed in R using the 'fields' package (Furrer et al., 2012). Interpolated $K_{\mathrm{T}}$ values were bounded below by the minimum value measured; the upper values were left unbounded. This resulted in estimated $K_{\mathrm{T}}$ values, which preserved the qualitative pattern and range of values previously reported (Jurado et al., 2012). In addition, the depth of the ML $\left(Z_{\mathrm{m}}\right)$ was determined as the depth at which the temperature difference with respect to the surface was $0.5^{\circ} \mathrm{C}$ (Levitus et al., 2000; Jurado et al., 2012). As shown by Brainerd and Gregg (1995), this definition of the ML provides an estimate of the depth through which surface waters have been mixed in recent days. On the few occasions where SCAMP data were not available, $Z_{\mathrm{m}}$ was determined from CTD data. Temperature profiles obtained from SCAMP and CTD measurements were compared and showed good agreement. To quantify the strength of stratification, CTD data were processed with SBE Seabird software (Sea-Bird Electronics) to calculate the Brunt-Väisälä frequency $\left(N^{2}\right.$, in $\left.\operatorname{rad}^{2} \mathrm{~s}^{-2}\right)$ using the Fofonoff adiabatic leveling method (Bray and Fofonoff, 1981). The Brunt-Väisälä frequency represents the angular velocity (that is, the rate) at which a small perturbation of the stratification will re-equilibrate. Hence, it is a simple measure of the stability of the vertical stratification.

In October-November 2011, an opportunity was presented to join the MEDEA (Microbial Ecology of the Deep Atlantic) cruise, to conduct additional modified dilution experiments in the oligotrophic area of the Northeast Atlantic Ocean (Figure 1). During MEDEA, physicochemical parameters were measured from three to five depths per station within the upper 120$\mathrm{m}$ water column using the same methods as for STRATIPHYT. However, no SCAMP measurements were conducted during MEDEA and ammonium concentrations were not determined. Samples for modified dilution assays were taken mostly from the DCM depth (Supplementary Table S1).

\section{Microbial abundances}

Viruses, bacteria, cyanobacteria and eukaryotic phytoplankton $<20 \mu \mathrm{m}$ were enumerated using a BectonDickinson (Erembodegem, Belgium) FACSCalibur flow cytometer (FCM) equipped with an air-cooled Argon laser with an excitation wavelength of $488 \mathrm{~nm}$ $(15 \mathrm{~mW})$. Approximately $1 \mathrm{ml}$ of fresh seawater was used for enumeration of phytoplankton using methods described by Marie et al. (2005). Phytoplankton were differentiated based on their autofluorescence properties using bivariate scatter plots of either orange (that is, phycoerythrin, present in Synechococcus spp.) or red fluorescence (that is, Chl $a$, present in all phytoplankton) against side scatter. Average cell size for phytoplankton subpopulations were determined by size fractionation of whole water by sequential gravity filtration through $8,5,3,2,1,0.8$ and $0.4 \mu \mathrm{m}$ pore-size polycarbonate filters, by assuming spherical diameter (Ø) of size displayed by the median (50\%) number of cells retained for that cluster. In total, eight distinct phytoplankton groups were detected and sized by sequential size-fractioned gravity filtration, that is, two picoeukaryotic groups (average $\varnothing$ of 1.4 and $1.5 \mu \mathrm{m}$, respectively), three nanoeukaryotic groups (3, 6 and $8 \mu \mathrm{m} \varnothing$, respectively) and three picocyanobacteria groups (Synechococcus spp. of $0.9 \mu \mathrm{m} \varnothing$ and ecotypes Prochlorococcus high light of $0.6 \mu \mathrm{m} \varnothing$ in surface waters and Prochlorococcus low light of $0.7 \mu \mathrm{m} \varnothing$ in the DCM).

Bacteria and viruses were enumerated according to Marie et al. (1999) and Brussaard et al. (2010), respectively, with modifications according to Mojica et al. (2014). Briefly, samples were fixed with $25 \%$ glutaraldehyde (EM-grade, Sigma-Aldrich, Zwijndrecht, The Netherlands) to a final concentration of $0.5 \%$ for $15-30 \mathrm{~min}$ at $4{ }^{\circ} \mathrm{C}$, flash frozen and stored at $-80^{\circ} \mathrm{C}$ until analysis. Thawed samples were diluted in TE buffer ( $\mathrm{pH}$ 8.2, $10 \mathrm{~mm}$ Tris HCl, 1 mm EDTA; Mojica et al., 2014), stained with the nucleic acidspecific green fluorescence dye SYBR Green I (final concentration of $1 \times 10^{-4}$ and $5 \times 10^{-5}$ of the commercial stock concentration; Life Technologies, Bleiswijk, 
The Netherlands) and incubated in the dark at either room temperature for $15 \mathrm{~min}$ or at $80^{\circ} \mathrm{C}$ for $10 \mathrm{~min}$, for bacteria and viruses, respectively. Cooled samples ( $5 \mathrm{~min}$, room temperature) were then analyzed on the flow cytometer with the discriminator set on green fluorescence. Five distinct virus groups, labeled V1-V5, were identified based on their green fluorescence and side scatter characteristics (Figure 2). Low fluorescing viral groups, V1 and V2, are considered to be primarily dominated by phages infecting heterotrophic bacteria, although some evidence suggests that eukaryotic algal viruses can also display similar low fluorescence signatures (Brussaard and Martinez, 2008; Brussaard et al., 2010). The other virus groups generally contain more algal viruses, with both proand eukaryotic algal viruses contributing to the V3 group, whereas the higher side scatter groups, V4 and V5, commonly represent large double-stranded DNA algal viruses (Jacquet et al., 2002; Brussaard, 2004b; Baudoux et al., 2006).

\section{Redundancy analysis}

We applied multivariate statistical analysis to data obtained from STRATIPHYT, to test hypotheses (H1) and (H2) put forth in the Introduction section. The analysis was performed using $\mathrm{R}$ statistical software (R Development Core Team, 2012) supplemented by the vegan package (Oksanen et al., 2013).

First, we performed a data exploration following the protocol described in Zuur et al. (2010). Most phytoplankton groups distinguished by flow cytometry had limited biogeographical distributions within our study area and consequently suffered from zero inflation (for example, zeroes in $>20 \%$ of the data points for almost every phytoplankton group). To avoid issues arising from zero inflation and provide good quality explanatory data, phytoplankton groups were clustered into different

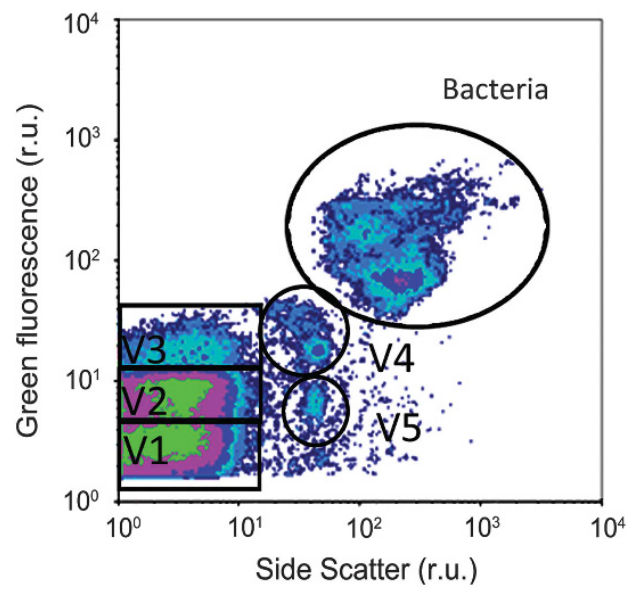

Figure 2 A typical dot plot of viruses counted with flow cytometry in a water sample of the STRATIPHYT cruise. Viruses (and bacteria) were discriminated by green fluorescence versus side scatter; V1-V5 indicate the five virus groups distinguished by flow cytometry. categories: total picocyanobacteria (Synechococcus, Prochlorococcus high-light ecotype and Prochlorococcus low-light ecotype), total picoeukaryotes (picoeukaryotes I+II), total nanoeukaryotes (nanoeukaryotes I+II+III) and total phytoplankton. For hypothesis (H1), the response variables were the abundances of the bacteria and different phytoplankton groups, and total Chl $a$, whereas the explanatory variables were latitude, vertical mixing coefficient $\left(K_{\mathrm{T}}\right.$, temperature eddy diffusivity), a stratification index ( $N^{2}$, Brunt-Väisälä frequency) and temperature. For hypothesis (H2), the response variables were the virus groups V1-V5 and total viral abundance, whereas the explanatory variables were the bacteria, different phytoplankton groups, total Chl $a$ and the environmental variables latitude $K_{\mathrm{T}}, N^{2}$ and temperature. Virus, bacteria, phytoplankton and chlorophyll data were $\log (x+1)$ transformed, and the vertical mixing coefficient and temperature were log transformed to improve the homogeneity of variance.

Next, to obtain the most parsimonious model, data were examined for collinearity of the explanatory variables by calculating variance inflation factors using the R function corvif (Zuur et al., 2009). In a stepwise manner, all explanatory variables with variance inflation factors $>8$ were removed from the model. For hypothesis (H1), variance inflation factor analysis resulted in the selection of four explanatory variables: latitude, $K_{\mathrm{T}}, N^{2}$ and temperature. For hypothesis (H2), variance inflation factor analysis resulted in the selection of eight explanatory variables: picocyanobacteria (Cyano), picoeukaryotic phytoplankton (PicoEUK), nanoeukaryotic phytoplankton (NanoEUK), bacteria, Chl $a$, latitude, $N^{2}$, $K_{\mathrm{T}}$ and temperature.

Initial scatterplots of the response and explanatory variables revealed strong linear relationships and therefore redundancy analysis (RDA) (Zuur et al., 2009) was chosen over canonical correspondence analysis. RDA is a combination of multiple regression analysis and principal component analysis for multivariate data. Forward selection was applied to select only those explanatory variables that contributed significantly to the $\mathrm{RDA}$ model, while removing nonsignificant terms. Significance was assessed by a permutation test, using the multivariate pseudo-F as test statistic (Zuur et al., 2009). A total of 9999 permutations were used to estimate $P$-values associated with the pseudo-F statistic.

RDA was based on all sampling points for which we had a complete data set of explanatory and response variables. For hypothesis (H1), this amounted to 80 samples (ranging from 0 to $225 \mathrm{~m}$ depth, with 4-11 depths sampled per station) from 15 stations of the STRATIPHYT cruise. For hypothesis (H2), the explanatory variable $N^{2}$ was not significant (see Results). Hence, RDA could be performed on 96 samples, as the removal of $N^{2}$ permitted the inclusion of sampling points from STRATIPHYT stations that lacked $N^{2}$ data. 
Modified dilution experiments

To investigate hypothesis (H3) we determined viral lysis and microzooplankton grazing rates of the different phytoplankton groups using the modified dilution assay according to Kimmance and Brussaard (2010). For both the STRATIPHYT and MEDEA cruises, experiments were conducted onboard, using water samples obtained from those depths where Chl $a$ autofluorescence was maximal (that is, DCM or ML). Natural seawater, gently passed through a $200-\mu \mathrm{m}$ mesh to remove mesozooplankton (while retaining microzooplankton), was combined with $0.45 \mu \mathrm{m}$ diluent or $30 \mathrm{kDa}$ ultrafiltrate in proportions of $100 \%, 70 \%, 40 \%$ and $20 \%$, to gradually decrease the mortality impact with increasing dilution (Supplementary Figure S1a). The $0.45 \mu \mathrm{m}$ filtrate, prepared with the goal of removing the microzooplankton grazers, was achieved by gravity filtration of natural seawater through a $0.45-\mu \mathrm{m}$ Sartopore capsule filter with a 0.8- $\mu \mathrm{m}$ prefilter (Sartopore 2300, Sartorius Stedim Biotech, Göttingen, Germany). The 30-kDa ultrafiltrate, prepared to remove grazers and viruses, was generated by tangential flow filtration using a polyethersulfone membrane (Vivaflow 200, Sartorius Stedim Biotech, Göttingen, Germany). All experiments were performed in triplicate in 1-liter clear polycarbonate bottles. After preparation of the two parallel dilution series (12 bottles each), a 3-ml subsample was taken and phytoplankton was enumerated by FCM as specified previously. The bottles were then incubated for $24 \mathrm{~h}$ in an on-deck flowthrough seawater incubator at in situ temperature and light (using neutral density screen) conditions. After the 24-h incubation period, a second FCM phytoplankton count was executed and the resulting growth rate for each phytoplankton group determined. Dual measurements of viral lysis and grazing rates were obtained for all phytoplankton groups, except for Prochlorococcus high light, which was largely absent from the sampled depths.

The microzooplankton grazing rate was estimated from the regression coefficient of the apparent growth rate versus fraction of natural seawater for the $0.45-\mu \mathrm{m}$ series, whereas the combined rate of viral-induced lysis and microzooplankton grazing was estimated from a similar regression for the 30$\mathrm{kDa}$ series (Supplementary Figures S1b and c) (Baudoux et al., 2006; Kimmance and Brussaard, 2010). A significant difference between the two regression coefficients (as tested by analysis of covariance) indicates a significant viral lysis rate. Phytoplankton gross growth rate ( $\mu_{\text {gross }}$, in the absence of grazing and viral lysis) was derived from the $y$ intercept of the $30-\mathrm{kDa}$ series regression.

The viral lysis and grazing rates were analyzed with a two-way analysis of variance with type II sum of squares, to assess differences between the two sources of mortality (viral lysis versus grazing) and among the phytoplankton groups (Synechococcus, Prochlorococcus low light, total picoeukaryotes and total nanoeukaryotes). Homogeneity of variance was confirmed by Levene's test and post-hoc comparison of the means was based on Tukey's honest significant difference test using SPSS version 22.0 (IBM Corp., Armonk, NY, USA). Potential relationships between biological parameters obtained from the modified dilution assays (for example, phytoplankton abundance, $\mu_{\text {gross }}$, viral lysis and grazing rates) and environmental parameters were examined by Spearman's rank correlation coefficient. Probability values were adjusted with Holm's correction for multiple hypothesis testing using the corr.p function of psych (Revelle, 2014) implemented in R (R Development Core Team, 2012). The correlation analysis was performed on the complete data set $(n=105)$ with a significance level $(\alpha)$ of 0.05 .

\section{Results}

During both the STRATIPHYT and MEDEA cruise, the North Atlantic was characterized by a strong temperature-induced vertical stratification resulting in very low concentrations of dissolved inorganic nitrogen and phosphorus in the upper 50-100 m water column at latitudes south of $45^{\circ} \mathrm{N}$ (Figures 3a-g and Supplementary Figure S2). Toward the north, stratification weakened, slightly relaxing nutrient limitation in the upper $50 \mathrm{~m}$ surface layer.

For both cruises, pico-sized phytoplankton $(<2 \mu \mathrm{m} \varnothing)$ accounted for more than $95 \%$ of the total phytoplankton $<20 \mu \mathrm{m}$ enumerated by FCM. South of $45^{\circ} \mathrm{N}$, both total phytoplankton abundance (up to $1.6 \pm 0.4 \times 10^{5}$ cells per $\mathrm{ml}$ ) and Chl $a$ (Figure $3 \mathrm{~g}$ and Supplementary Figure S2e) were maximal between 30 and $100 \mathrm{~m}$ depth, characteristic of a DCM. Cyanobacteria were the most abundant members of the phytoplankton community in this southern region (Figure 4a) and consisted mainly of Prochlorococcus high light and Prochlorococcus low light (Supplementary Figures S3a and b). The DCM shallowed with latitude, giving over to a surface maximum north of $45^{\circ} \mathrm{N}$, marking the northern boundary of the oligotrophic areas (defined by $\mathrm{Chl}$ a concentrations $<0.07 \mathrm{mg} \mathrm{Chl}$ per $\mathrm{m}^{3}$; Polovina et al., 2008). Cyanobacterial abundance decreased with the loss of the DCM and disappearance of Prochlorococcus spp. north of $45^{\circ} \mathrm{N}$ (Figure $4 \mathrm{a}$ and Supplementary Figures S3a and b). However, the cyanobacteria Synechococcus spp. showed highest abundances in the most northern stations, beyond $56^{\circ} \mathrm{N}$, where they numerically dominated the photosynthetic community $<20 \mu \mathrm{m}$ (Supplementary Figure S3c). Picoeukaryotic and nanoeukaryotic phytoplankton were relatively abundant in the DCM between $38^{\circ} \mathrm{N}$ and $45^{\circ} \mathrm{N}$, and reached maximal abundances in the surface waters of the stations north of $54^{\circ} \mathrm{N}$ (Figures $4 \mathrm{~b}$ and c,and Supplementary Figures S3d-h). Bacterial abundance was maximal in the surface waters of the most northern stations (Figure 4d). 

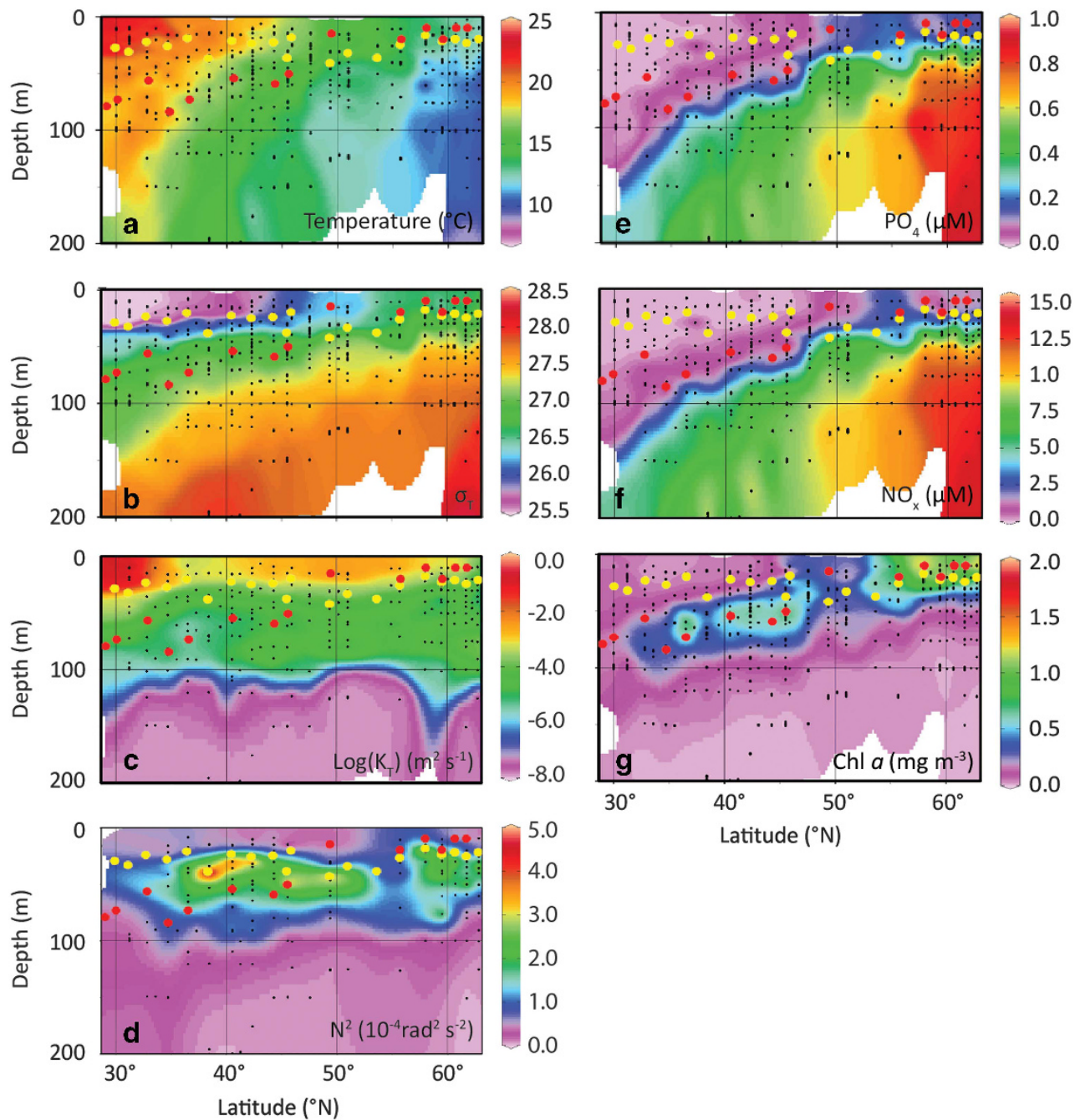

Figure 3 Latitudinal and depth distribution of (a) temperature, (b) $\sigma_{\mathrm{T}}$, (c) temperature eddy diffusivity $\left(K_{\mathrm{T}}\right)$, (d) Brunt-Väisälä frequency $\left(N^{2}\right)$, (e) inorganic phosphorus, (f) $\mathrm{NO}_{x}$ (nitrate+nitrite) and (g) Chl $a$ concentrations measured during STRATIPHYT. Black dots indicate sampling points, yellow dots indicate ML depth $\left(Z_{\mathrm{m}}\right)$ and red dots indicate the sampling depths for modified dilution assays. Figure panels were prepared using Ocean Data View (ODV version 4.6.5, Schlitzer, 2002).

The five virus groups showed distinct biogeographical distributions (Figures 4e-i). Although V1 and V2 viruses were the numerically dominant virus groups in the DCM of the strongly stratified waters below $45^{\circ} \mathrm{N}$, they were even more abundant in the top $50 \mathrm{~m}$ of the weakly stratified waters at latitudes above $45^{\circ} \mathrm{N}$ (Figures $4 \mathrm{e}$ and f). Conversely, V3 viruses reached their highest abundances between 30 and $100 \mathrm{~m}$ depth in the DCM of stratified waters south of $45^{\circ} \mathrm{N}$ (Figure $4 \mathrm{~g}$ ). V4 and V5 viruses were present throughout the latitudinal range, but V4 reached its maximum abundance in the subsurface waters located between latitudes $40-45^{\circ} \mathrm{N}$ (Figure 4h) and V5 had its highest abundance in the upper $50 \mathrm{~m}$ surface waters in the weakly stratified waters at the higher latitudes (Figure 4i).

The hypothesis (H1) that abundances and composition of the microbial host populations (for example, bacteria and phytoplankton) vary with latitude (H1a) and are strongly affected by changes in water column stratification (H1b) is confirmed by the RDA results.
Forward selection revealed that latitude and the stratification variables $K_{\mathrm{T}}, N^{2}$ and temperature all contributed significantly to the RDA model (Table 1). The results are presented in an RDA triplot (Figure 5a). The first two axes in the RDA triplot explained $27 \%$ and $4 \%$ of the variation in the data, respectively. The concentrations of bacteria, cyanobacteria, picoeukaryotic and nanoeukaryotic phytoplankton were all positively correlated with $K_{\mathrm{T}}$ and $N^{2}$. The strong positive correlation between picoeukaryotes and $N^{2}$ is particularly noteworthy, indicating that picoeukaryotes reached their highest concentrations at or near the pycnocline. In comparison with the other species groups, cyanobacteria showed a relatively strong correlation with temperature and nanoeukaryotes a relatively strong correlation with latitude.

RDA was also applied to investigate hypothesis (H2) that the biogeographical distributions of the viruses depend on the biogeographical distributions of their hosts. Forward selection revealed that 

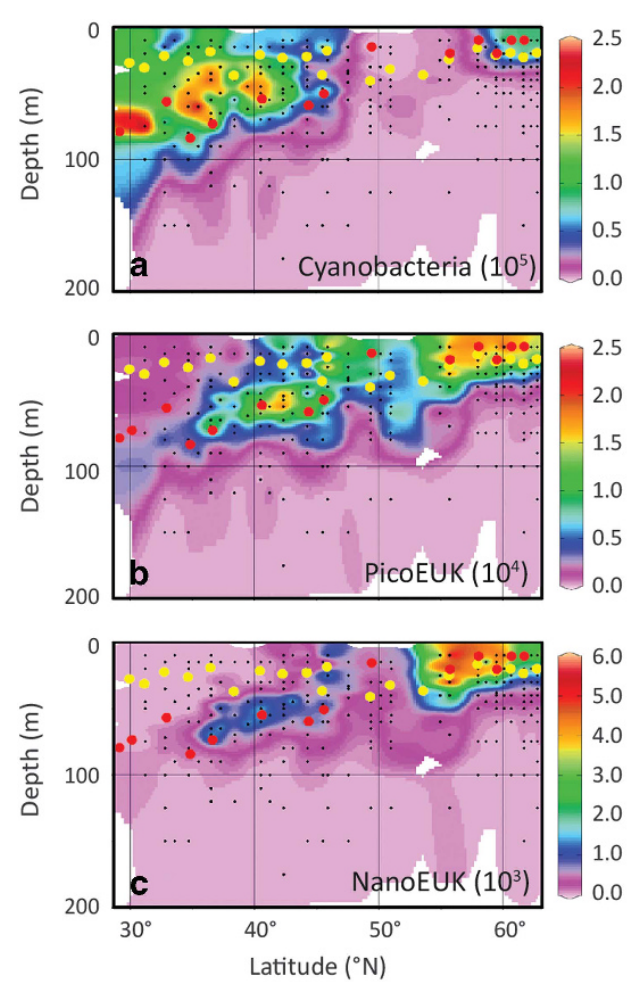
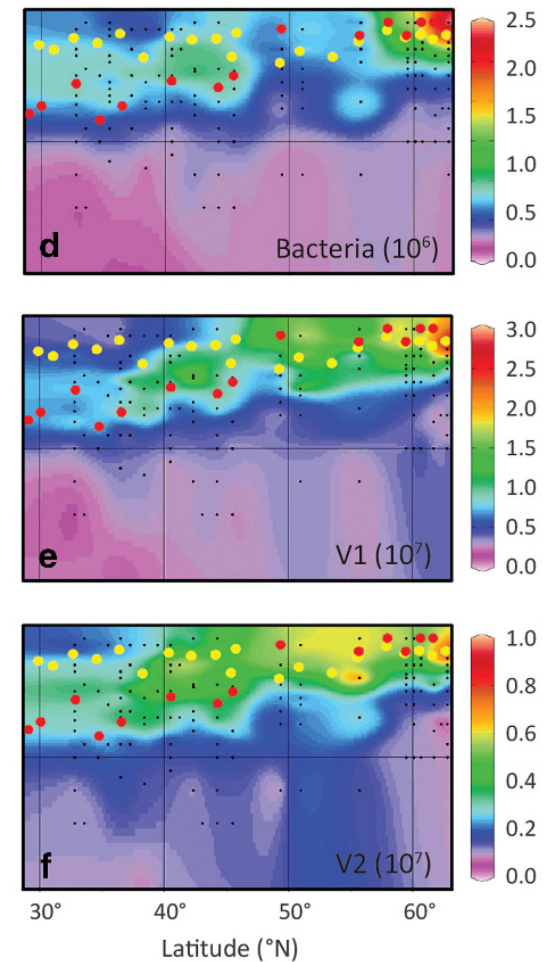
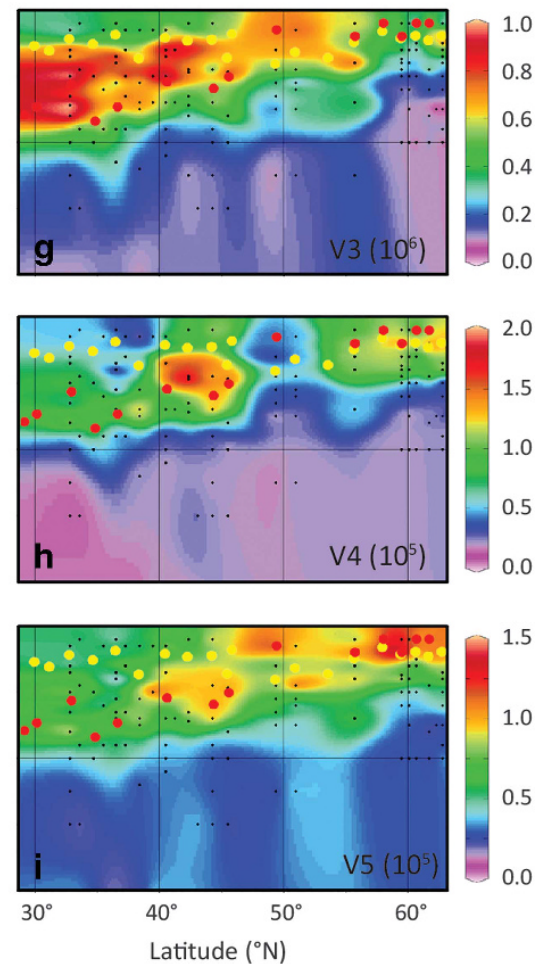

Figure 4 Biogeographical distributions of phytoplankton (a-c), bacteria (d) and virus groups (e-i) across the Northeast Atlantic Ocean based on flow cytometry counts obtained during the STRATIPHYT cruise. Abundances are expressed in (a-c) cells per ml, (d) bacteria per $\mathrm{ml}$ and $(\mathbf{e}-\mathbf{i})$ viruses per ml. Black dots indicate sampling points, yellow dots indicate ML depth $\left(Z_{\mathrm{m}}\right)$ and red dots indicate the sampling depths for modified dilution assays. Graphs were prepared with Ocean Data View (ODV version 4.6.5, Schlitzer, 2002).

Table 1 Significance of the selected explanatory variables in the RDA correlation triplots (see Figure $5 \mathrm{a}$ and $\mathrm{b}$ )

\begin{tabular}{lrcc}
\hline Explanatory variable & AIC & Pseudo-F & P-values \\
\hline Host populations (H1) & & & \\
$\quad K_{\mathrm{T}}$ & 103.5 & 33 & 0.005 \\
$\quad$ Temperature & 95.4 & 10.4 & 0.005 \\
Latitude & 79.7 & 18.9 & 0.005 \\
$N^{2}$ & 71.1 & 10.6 & 0.005 \\
& & & \\
Virus populations (H2) & & & \\
Bacteria & 89.5 & 135.0 & 0.005 \\
PicoEUK & 71.7 & 21.4 & 0.005 \\
NanoEUK & 64.8 & 8.9 & 0.005 \\
Temperature & 58.5 & 8.3 & 0.005 \\
Cyano & 54.1 & 6.1 & 0.005 \\
Latitude & 52.9 & 3.1 & 0.025 \\
\hline
\end{tabular}

Abbreviations: AIC, Akaike Information Criterion; NanoEUK, nanoeukaryotic; PicoEUK, picoeukaryotic; RDA, redundancy analysis. The explanatory variables were selected by forward selection based on the pseudo-F statistic, using 9999 permutations to assess their significance. Total variation explained by the RDA models was $57 \%$ and $75 \%$, respectively.

latitude, temperature and the four different potential host groups contributed significantly to the RDA model (Table 1), whereas the environmental variables $K_{\mathrm{T}}$, Chl $a$ and $N^{2}$ (pseudo-F=1.1, 0.8 and 0.2 ; $P=0.39,0.53$ and 0.91 , respectively) did not. The first two axes of the RDA triplot (Figure 5b) explained $51 \%$ and $3 \%$ of the variation in the data, respectively. In line with expectation, the RDA triplot shows that the biogeographical distribution of V1 viruses was tightly coupled to the distribution of total bacterial abundance (Figure 5b).The distribution of V2 viruses was correlated with total picoeukaryotic phytoplankton abundance, whereas the distribution of V3 viruses was strongly correlated with total picocyanobacterial abundance. Furthermore, distributions of V4 and V5 viruses were associated with high abundances of nanoeukaryotic phytoplankton and bacteria (Figure 5b).

To assess hypothesis (H3), we quantified the contributions of viral lysis and grazing to the mortality of the different phytoplankton groups by conducting 34 modified dilution assays across the North Atlantic during the two cruises (Figure 1 and see Supplementary Tables S1 and S2 for details). We first tested whether the modified dilution assays themselves had any undesirable side effects on phytoplankton performance. In general, we found no associated reduction in growth rate for any of the phytoplankton groups in the $20 \%$ fraction of the 30Ka series, where potential enhanced nutrient limitation would be greatest due to reduced remineralization (as a result of removal of bacteria and grazers). Furthermore, the photosynthetic capacity remained high for all dilutions $\left(F_{\mathrm{v}} / F_{\mathrm{m}}=0.6\right)$.

Viral lysis rates varied from 0 to 1.05 per day (Supplementary Figure S2). Two-way analysis of variance of the mortality rates revealed a significant main effect of the phytoplankton groups 

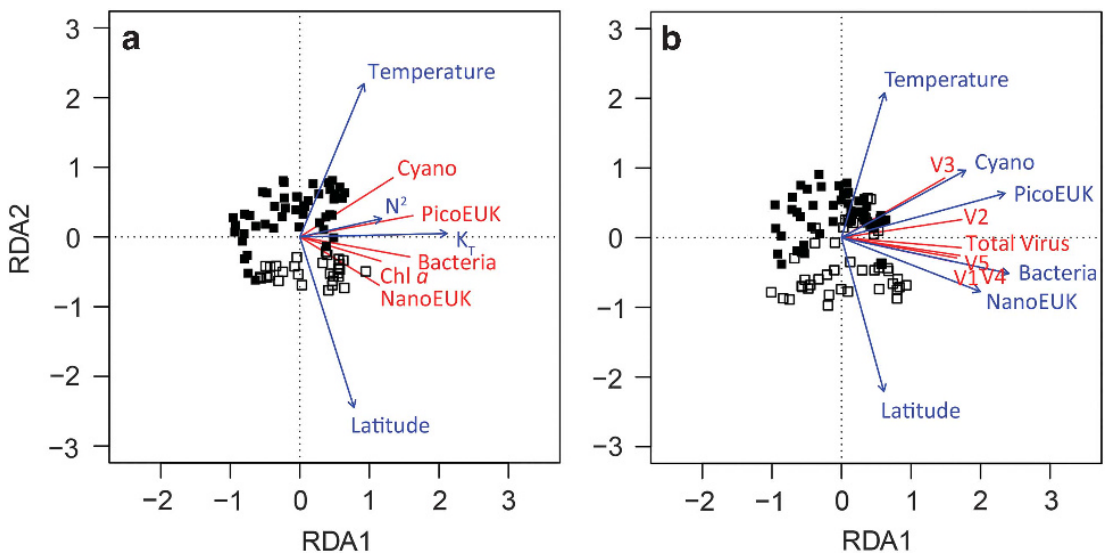

Figure 5 RDA correlation triplot describing (a) the biogeographical distribution of potential microbial hosts (response variables, in red) in relation to environmental variables relevant to stratification (explanatory variables, in blue) and (b) the biogeographical distributions of the viruses (response variables, in red) in relation to latitude and the biogeographical distributions of their hosts (explanatory variables, in blue) using data obtained during the STRATIPHYT cruise. Symbols represent individual sampling points ( $n=80$ and 96 in a and $\mathbf{b}$, respectively), where closed squares represent sampling points at stations with a DCM and open squares represent sampling points at stations without a DCM. The DCM was defined by the presence of a subsurface peak in the vertical profile of Chl $a$ autofluorescence, which is a common feature of vertically stratified oligotrophic waters. All explanatory variables in the triplot are significant (Table 1). Total variation explained by the RDA models in a and $\mathbf{b}$ was $57 \%$ and $75 \%$, respectively.

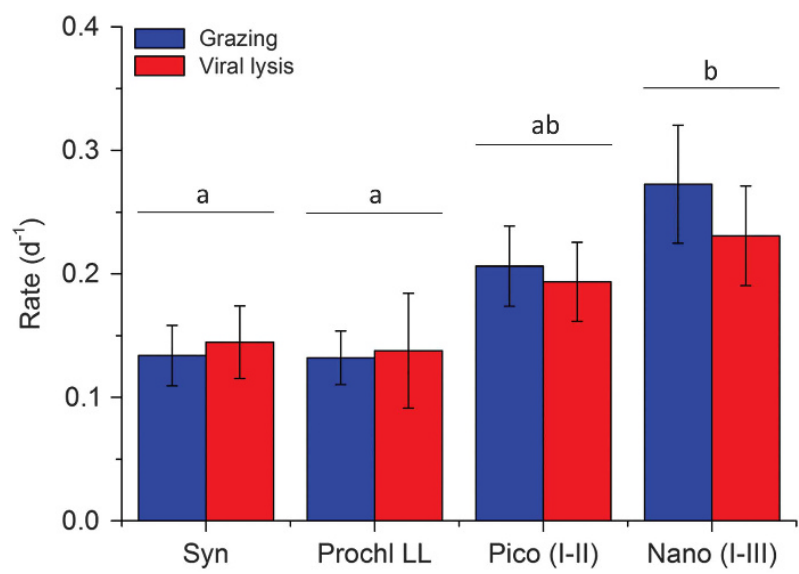

Figure 6 Grazing and viral lysis rates of the different phytoplankton groups. Grazing and viral lysis rates were determined using the modified dilution assay. The phytoplankton groups include Synechococcus (Syn, sample size $N=19$ ), low-lightadapted Prochlorococcus (Prochl LL, $N=13$ ), picoeukaryotes (Pico I-II, $N=45$ ) and nanoeukaryotes (Nano I-III, $N=28$ ). High-lightadapted Prochlorococcus was largely absent at the depths sampled for the modified dilution assays. Error bars S.E. Bars with different letters are significantly different $(P<0.05)$, as tested by two-way analysis of variance followed by post-hoc comparison of the means using Tukey's honest significant difference.

$\left(\mathrm{F}_{3,188}=4.761, P=0.003\right)$, whereas the main effect of the mortality source (grazing vs viral lysis) $\left(\mathrm{F}_{1,188}=2.316, P>0.05\right)$ and the interaction term $\left(\mathrm{F}_{3,188}=0.115, P>0.05\right)$ were both nonsignificant. In other words, viral lysis rates were comparable to microzooplankton grazing rates for all phytoplankton groups measured (Figure 6), demonstrating that virus-mediated lysis contributed to approximately half of the total phytoplankton mortality. However, mortality rates differed between the phytoplankton groups. The mortality rates of nanoeukaryotic and picoeukaryotic phytoplankton were not significantly different, and these two groups demonstrated the highest average viral lysis rates of 0.23 and 0.19 per day and grazing rates of 0.27 and 0.21 per day, respectively (Figure 6). Synechococcus and Prochlorococcus experienced significantly lower mortality rates compared with the nanoeukaryotes, with viral lysis rates of 0.14 per day and grazing rates of 0.13 per day.

Total mortality rates of the specific phytoplankton groups ranged from 0.01 to 1.20 per day and were in balance with gross growth rates (Figure 7a), emphasizing fast turnover of the photoautotrophic production. Moreover, our data show a remarkable reduction in the ratio of viral lysis rates to microzooplankton grazing rates $(\mathrm{V}: \mathrm{G})$ at higher latitudes $\left(>56^{\circ} \mathrm{N}\right.$ ) (Figure $7 \mathrm{~b}$ ). This switch from a viral lysisdominated to a grazing-dominated plankton community was consistent across different phytoplankton groups (Figure 7b). The pattern is corroborated by a significant negative correlation of $\mathrm{V}: \mathrm{G}$ with latitude and a significant positive correlation with temperature and salinity (Table 2). Similarly, viral lysis rates but not the grazing rates showed a significant negative correlation with latitude and $K_{\mathrm{T}}$, and positive correlation with temperature and salinity, suggesting that the reduction in $\mathrm{V}: \mathrm{G}$ was due to decreased viral lysis rates at higher latitudes (Table 2).

\section{Discussion}

Our results demonstrate distinct biogeographical distributions of different virus groups and their potential host microbial populations across the North Atlantic Ocean (Figure 4). Metagenomic analyses of marine viral assemblages suggest that most viruses are widely dispersed across different oceanic regions (Angly et al., 2006), providing a seeding community for recruitment once the 
508
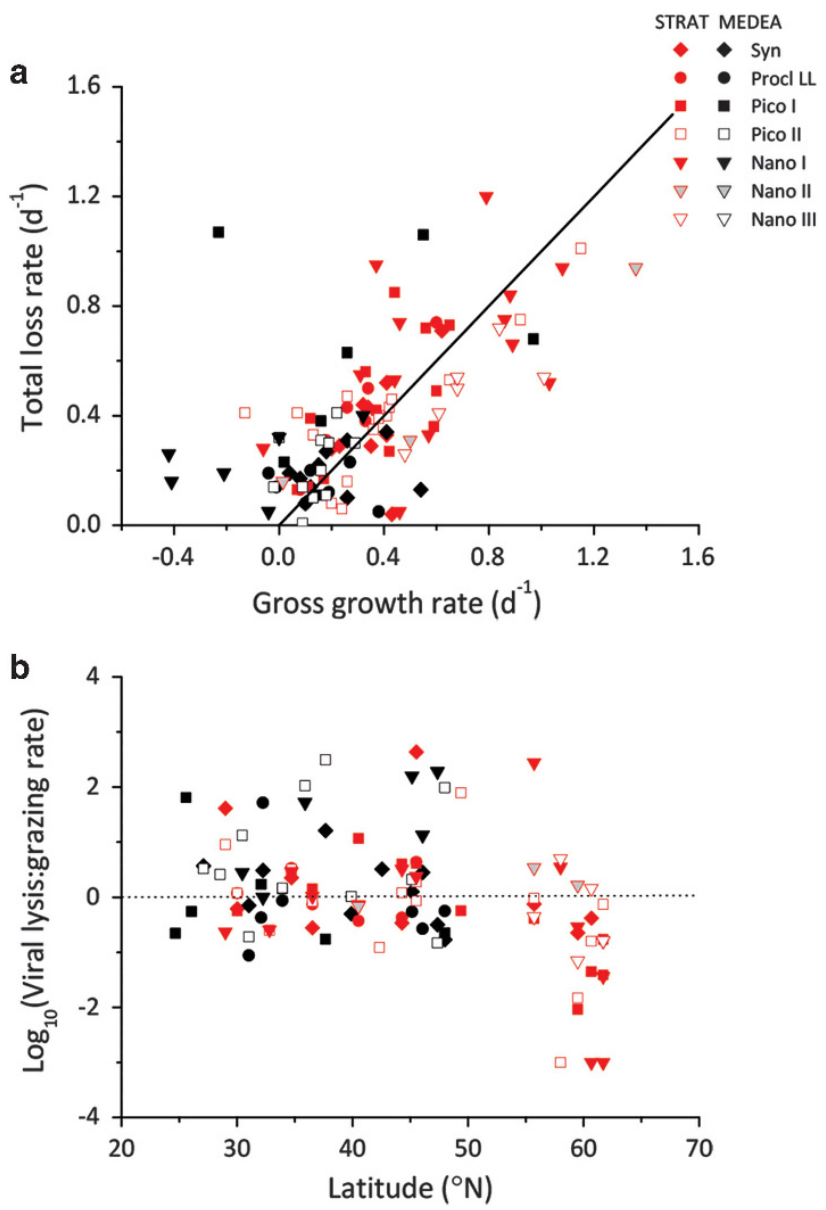

Figure 7 The contribution of viral lysis to phytoplankton mortality. (a) Relationship between the total loss rate (grazing +viral lysis) and gross growth rate of the seven phytoplankton groups $(<20 \mu \mathrm{m})$. The black line indicates a 1:1 relationship. (b) Ratio of viral lysis to microzooplankton grazing rates for each of the seven phytoplankton groups $(<20 \mu \mathrm{m})$ distinguished by flow cytometry, as function of latitude. Rates were obtained by the modified dilution technique during the STRATIPHYT (red symbols) and MEDEA (black symbols) cruises. High-lightadapted Prochlorococcus were not included, as they were largely absent at the depths sampled for the modified dilution assays. Dotted line indicates a 1:1 relationship of viral lysis to grazing.

environmental conditions turn favorable (Breitbart and Rohwer, 2005; Suttle, 2007; Thingstad et al., 2014). Therefore, the classical tenet of 'all microbes are everywhere, but the environment selects' (Baas Becking, 1931; de Wit and Bouvier, 2006) is likely to apply to marine viruses. Accordingly, large-scale biogeographical variation in viral composition across the oceans is probably not caused by dispersal limitation but largely due to spatial variation in environmental conditions (Figure 5a). In particular, in agreement with hypothesis (H1) and (H2), our results show that the observed biogeographical distributions of marine viruses across the North Atlantic are strongly associated with the distributions of bacteria and phytoplankton that serve as their main hosts (Figure 5b). The large-scale distributions of these host species are in turn dependent on the latitudinal gradient from warm permanently stratified waters in the subtropical North Atlantic to colder seasonally stratified waters at higher latitudes (Figure 5a).

Yang et al. (2010) described a correlation between V3 viruses and picophytoplankton (including picocyanobacteria and picoeukaryotes) in the Pacific Ocean, with highest V3 virus abundances in tropical and subtropical waters. Our results show that the distribution of V3 viruses is closely related to the distribution of picocyanobacteria (Prochlorococcus and Synechococcus) (Figure 5b), indicating that the cluster of V3 viruses contains many cyanophages, which is in line with previous observations that cyanophages are particularly widespread in the (sub)tropical oceans (Suttle and Chan, 1994; Wilson et al., 1999; Angly et al., 2006). In contrast, the distribution of V2 viruses appears to be linked to picoeukaryotic phytoplankton and both the V2 viruses and picoeukaryotic phytoplankton are abundant at mid and high latitudes (Figures $4 \mathrm{~b}$ and $\mathrm{f}$, and Figure 5b). Furthermore, our observation that V4 and V5 viruses are correlated to nanoeukaryotic phytoplankton (Figure 5b) corroborates earlier studies documenting similar FCM signatures for viruses infective against haptophytes (Jacquet et al., 2002; Brussaard, 2004b; Baudoux et al., 2006).

The fate of primary production has important implications for the ecology and biogeochemical recycling of marine food webs. Estimates of viral lysis rates of natural phytoplankton populations remain scarce, and consequently the importance of viruses in comparison with other loss factors remains unclear. Rates of viral-mediated mortality for Synechococcus (that is, 0.03-0.49 per day), picoeukaryotic phytoplankton (that is, 0-0.81 per day) and nanoeukaryotic phytoplankton (that is, 0-1.05 per day) were comparable to the ranges reported in the literature (Baudoux et al., 2007, 2008; Evans and Brussaard, 2012; Tsai et al., 2012). The viral lysis rates of Prochlorococcus (that is, 0.02-0.57 per day) presented here were higher than the maximal 0.06 per day reported thus far (Baudoux et al., 2007). The typical set-up of the modified dilution assay (that is, two parallel series, four dilutions and three replicates) lacks the sensitivity required to detect significance of viral lysis rates when rates are very low (Evans et al., 2003; Kimmance et al., 2007; Baudoux et al., 2008). Hence, we note that estimates of viral lysis rates $<0.1$ per day should be interpreted with caution. To improve sensitivity of the method at low viral lysis rates, more replicates should be used.

Among the different phytoplankton groups, Synechococcus and Prochlorococcus experienced the lowest average viral lysis rates (that is, 0.14 per day) (Figure 6). Considering the dominance of cyanophages and their hosts, the low viral mortality may seem surprising (Suttle and Chan, 1993; Wang et al., 2011). However, Synechococcus and Prochlorococcus populations display high genotypic diversity and have the ability to develop resistance against 
Table 2 Spearman rank correlation coefficients and associated $P$-values of environmental and biological data

\begin{tabular}{|c|c|c|c|c|c|c|c|c|c|c|c|c|c|c|}
\hline & Latitude & Temperature & Salinity & $\sigma_{T}$ & $\mathrm{~K}_{T}$ & $\mathrm{~N}^{2}$ & $\mathrm{PO}_{4}$ & $N O_{x}$ & $\mathrm{P}_{o}$ & $\mu_{\text {gross }}$ & G & $\mathrm{V}$ & $\mathrm{T}_{M}$ & $\mathrm{~V}: \mathrm{G}$ \\
\hline Latitude & & -0.95 & -0.96 & -0.67 & 0.68 & n.s. & 0.76 & 0.57 & n.s. & n.s. & n.s. & -0.47 & n.s. & -0.47 \\
\hline Temperature & 0.00 & & 0.89 & 0.56 & -0.66 & n.s. & -0.79 & -0.61 & n.s. & n.s. & n.s. & 0.39 & n.s. & 0.41 \\
\hline Salinity & 0.00 & 0.00 & & 0.72 & -0.65 & n.s. & -0.77 & -0.57 & n.s. & n.s. & n.s. & 0.45 & n.s. & 0.47 \\
\hline$\sigma_{\mathrm{T}}$ & 0.00 & 0.00 & 0.00 & & -0.76 & n.s. & -0.65 & -0.44 & n.s. & n.s. & n.s. & 0.48 & n.s. & 0.36 \\
\hline$K_{\mathrm{T}}$ & 0.00 & 0.00 & 0.00 & 0.00 & & n.s. & 0.63 & 0.43 & n.s. & n.s. & n.s. & -0.43 & n.s. & n.s. \\
\hline$N^{2}$ & 1.00 & 1.00 & 1.00 & 1.00 & 0.34 & & n.s. & n.s. & n.s. & n.s. & n.s. & n.s. & n.s. & n.s. \\
\hline $\mathrm{PO}_{4}$ & 0.00 & 0.00 & 0.00 & 0.00 & 0.00 & 1.00 & & 0.89 & n.s. & n.s. & n.s. & n.s. & n.s. & n.s. \\
\hline $\mathrm{NO}_{x}$ & 0.00 & 0.00 & 0.00 & 0.00 & 0.00 & 1.00 & 0.00 & & n.s. & n.s. & n.s. & n.s. & n.s. & n.s. \\
\hline$P_{0}$ & 1.00 & 1.00 & 1.00 & 1.00 & 1.00 & 1.00 & 1.00 & 1.00 & & -0.51 & n.s. & n.s. & -0.38 & n.s. \\
\hline$\mu_{\text {gross }}$ & 1.00 & 1.00 & 1.00 & 1.00 & 1.00 & 0.54 & 1.00 & 1.00 & 0.00 & & 0.43 & n.s. & 0.64 & n.s. \\
\hline$G$ & 0.94 & 1.00 & 0.28 & 1.00 & 1.00 & 1.00 & 0.70 & 1.00 & 1.00 & 0.00 & & n.s. & 0.67 & -0.68 \\
\hline V & 0.00 & 0.00 & 0.00 & 0.00 & 0.00 & 1.00 & 0.41 & 1.00 & 0.36 & 0.40 & 1.00 & & 0.48 & 0.76 \\
\hline$T_{\mathrm{M}}$ & 1.00 & 1.00 & 1.00 & 1.00 & 1.00 & 1.00 & 1.00 & 1.00 & 0.00 & 0.00 & 0.00 & 0.00 & & n.s. \\
\hline$V: G$ & 0.00 & 0.00 & 0.00 & 0.01 & 0.11 & 1.00 & 0.22 & 1.00 & 1.00 & 1.00 & 0.00 & 0.00 & 1.00 & \\
\hline
\end{tabular}

Abbreviations: $G$, grazing rate; MEDEA, Microbial Ecology of the Deep Atlantic; $\mu_{\text {gross }}$, gross growth rate; n.s. indicates non-significance at $\alpha=0.05$; STRATIPHYT, changes in vertical stratification and its impacts on phytoplankton communities; $P_{0}$, phytoplankton host abundance; $T_{\mathrm{M}}$, total mortality rate; $V$, viral lysis rate; $V: G$, ratio of viral lysis to grazing rate.

Spearman's rank correlation coefficients (above the diagonal) and associated $P$-values (below the diagonal, with significant values highlighted in bold) of environmental and biological data obtained from modified dilution assays conducted during the STRATIPHYT and MEDEA cruises $(N=105)$.

viral infection (Waterbury and Valois, 1993; Scanlan and West, 2002), which could potentially reduce the impact of viral-induced mortality of these phytoplankton groups.

Virus-mediated lysis was responsible for approximately half of the total phytoplankton mortality in all four phytoplankton groups that we investigated, and comparable in magnitude to the mortality rate exerted by microzooplankton grazing (Figure 6). Total mortality of phytoplankton populations was in balance with gross growth (Figure 7a), indicating fast turnover of the photoautotrophic production within the North Atlantic Ocean. These results emphasize the need for the incorporation of viral lysis into ecosystems models (Franks, 2001; Keller and Hood, 2011; Keller and Hood, 2013). Moreover, our results support hypothesis (H3) that viral lysis rates vary with latitude, and point at a striking reduction in the ratio of viral lysis rates to grazing rates of marine phytoplankton at higher latitudes (Figure 7b). Although this observation might be a local or seasonal phenomenon, our findings are consistent with a smaller-scale study in the North Sea (Baudoux et al., 2008), which reported low viral lysis rates of picophytoplankton in offshore waters above $55^{\circ} \mathrm{N}$. Furthermore, data from the Southern Ocean point at low viral lysis rates of phytoplankton over a relatively broad geographic range from at least $43^{\circ} \mathrm{S}$ to $70^{\circ} \mathrm{S}$ on the southern hemisphere (Evans and Brussaard, 2012). This suggests that low viral lysis rates at higher latitudes are not unique for our data set, but may represent a global pattern.

The underlying causes for the reduction in viral lysis rates with latitude remain unclear. Our results reveal a positive relationship between temperature and viral lysis rates of marine phytoplankton. Although temperature has been shown to regulate viral infection of marine phytoplankton (Cottrell and Suttle, 1995; Nagasaki and Yamaguchi, 1998), evidence that temperature affects viral production rates is thus far largely restricted to bacterial hosts (Matteson et al., 2012; Mojica and Brussaard, 2014). Vertical stratification represses turbulence and reduces ML depth, thereby determining the general availability of light and nutrients to phytoplankton in the ocean (Behrenfeld et al., 2006; Huisman et al., 2006). These factors have been shown to be important factors regulating the production of viruses in phytoplankton hosts (Van Etten et al., 1983; Bratbak et al., 1998; Jacquet et al., 2002; Maat et al., 2014). Yet, we did not find a significant association between viral lysis rates and nutrient concentrations, host abundance or growth rate in our data (Table 2). In addition, viral lysis rates declined with latitude despite the latitudinal increase in total virus abundance, as well as increases in V1 and V2 viruses (Figure 4 and Supplementary Table S3). An exception is the decline of the V3 viruses with latitude (Figure 4g and Supplementary Table S3), which was due to the dominance of their picocyanobacterial hosts in the (sub)tropical southern region. Metagenomic analysis has revealed that lysogeny and prophage-like sequences are common in the Arctic Ocean (Angly et al., 2006). If this is a more general feature at higher latitudes, it may reduce the lytic viral lysis rates measured by the dilution assay. However, evidence for lysogeny in photoautotrophs is mostly restricted to prokaryotes (Paul, 2008). Consequently, lysogeny would not fully explain the low viral lysis rates at higher latitudes for eukaryotic phytoplankton populations. An alternative explanation might be that latitudinal changes in phytoplankton species composition result in more virus-resistant phytoplankton species at higher latitudes; however, we have no evidence to support this. We speculate that removal or inactivation rates of marine viruses by transparent exopolymer particles might be higher at the higher latitudes (Brussaard et al., 2005b; Mari et al., 2007). Transparent exopolymer particle concentrations have been found to 
be correlated to phytoplankton biomass, photosynthetic activity and bacterial production (Claquin et al., 2008; Ortega-Retuerta et al., 2010), which were highest in the northern latitudes of our study (see also van de Poll et al., 2013). As fluid shear is one of the primary factors controlling aggregation in pelagic systems (Jackson, 1990; Malits and Weinbauer, 2009), the increase of $K_{\mathrm{T}}$ with latitude might have promoted higher aggregate formation and increase the potential for viral (temporary) inactivation rates at higher latitudes.

Owing to deep water formation, the North Atlantic is key to ocean circulation and global climate, absorbing $\sim 23 \%$ of the global anthropogenic $\mathrm{CO}_{2}$ emission (Sabine et al., 2004). Several studies predict that global warming will result in a stronger temperature stratification in the North Atlantic Ocean (Sarmiento, 2004; Polovina et al., 2008), accompanied by changes in phytoplankton community structure, as oligotrophic regions of the ocean expand northwards (Flombaum et al., 2013; Mojica et al., 2015). This in turn will result in alterations to virus community structure, as virus populations respond to changing host distributions. Currently, grazing dominates phytoplankton mortality at higher latitudes, whereas the contribution of viral lysis is relatively small. However, our results indicate that warming of the surface layers will shift the ecosystem at high latitudes toward a more viral-lysisdominated system. The partitioning of photosynthetic carbon through these different pathways (that is, grazing versus cell lysis) has important implications for ecosystem function as each pathway differentially affects the structure and functioning of pelagic microbial food webs. Grazing transfers carbon, nutrients and energy to higher trophic levels, thereby increasing the overall efficiency and carrying capacity of the ecosystem. In addition, the production of fecal pellets by mesozooplankton is responsible for much of the carbon transported out of the euphotic zone into the deeper ocean (Ducklow et al., 2001). Viral lysis redirects carbon and energy away from larger organisms toward the microbial loop, and thereby rapidly returns most of the organic carbon fixed by phytoplankton into the surface layer (Fuhrman, 1999; Wilhelm and Suttle, 1999; Brussaard et al., 2005a; Weitz and Wilhelm, 2012). A more prominent role of viral lysis in the northern North Atlantic would thus markedly reduce biological carbon export into the ocean's interior in one of the key areas of global carbon sequestration, reducing the ocean's capacity to function as a long-term sink for anthropogenic carbon dioxide.

\section{Conflict of Interest}

The authors declare no conflict of interest

\section{Acknowledgements}

We thank the captains and crews of the $R / V$ Pelagia for their great help with sampling during the cruises.
Furthermore, we thank Jan Finke, Douwe Maat, Richard Doggen and Anna Noordeloos for their on-board assistance, Lisa Hahn-Woernle for providing the physical data, Klaas Timmermans for providing $F_{\mathrm{v}} / F_{\mathrm{m}}$ measurements and Harry Witte for his useful discussions regarding statistical analysis. This research was part of the STRATIPHYT project (ZKO-grant 839.08.420 for CPDB), supported by the Earth and Life Sciences Foundation (ALW), which is subsidized by the Netherlands Organisation for Scientific Research (NWO). We further acknowledge the OPTIMON project (ZKO) for JH and KDAM, the Turner-Kirk Charitable Trust of the Isaac Newton Institute for JH and NSF grants OCE-1061352 and OCE- 1030518 for SWW.

\section{References}

Angly FE, Felts B, Breitbart M, Salamon P, Edwards RA, Carlson C et al. (2006). The marine viromes of four oceanic regions. PLoS Biol 4: e368.

Baas Becking LGM. (1931). Geobiologie of inleiding tot de milieukunde. W.P. Van Stockum \& Zoon: The Hague, The Netherlands.

Baudoux AC, Noordeloos AAM, Veldhuis MJW, Brussaard CPD. (2006). Virally induced mortality of Phaeocystis globosa during two spring blooms in temperate coastal waters. Aquat Microb Ecol 44: 207-217.

Baudoux AC, Veldhuis MJW, Witte HJ, Brussaard CPD. (2007). Viruses as mortality agents of picophytoplankton in the deep chlorophyll maximum layer during IRONAGES III. Limnol Oceanogr 52: 2519-2529.

Baudoux AC, Brussaard CPD. (2008). Influence of irradiance on virus-algal host interactions. J Phycol 44: 902-908.

Baudoux AC, Veldhuis MJW, Noordeloos AAM, van Noort G, Brussaard CPD. (2008). Estimates of virus- vs. grazing induced mortality of picophytoplankton in the North Sea during summer. Aquat Microb Ecol 52: 69-82.

Behrenfeld MJ, O 'Malley RT, Siegel DA, McClain CR, Sarmiento JL, Feldman GC et al. (2006). Climate-driven trends in contemporary ocean productivity. Nature 444: $752-755$.

Brainerd KE, Gregg MC. (1995). Surface mixed and mixing layer depths. Deep Sea Res Part I 42: 1521-1543.

Bratbak G, Jacobsen A, Heldal M, Nagasaki K, Thingstad F. (1998). Virus production in Phaeocystis pouchetii and its relation to host cell growth and nutrition. Aquat Microb Ecol 16: 1-9.

Bray NA, Fofonoff NP. (1981). Available potential energy for mode eddies. J Phys Oceanogr 11: 30-47.

Breitbart M, Rohwer F. (2005). Here a virus, there a virus, everywhere the same virus? Trends Microbiol 13: 278-284.

Brussaard CPD. (2004a). Viral control of phytoplankton populations-a review. J Eukaryot Microbiol 51: 125-138.

Brussaard CPD. (2004b). Optimization of procedures for counting viruses by flow cytometry. Appl Environ Microbiol 70: 1506-1513.

Brussaard CPD, Kuipers B, Veldhuis MJW. (2005a). A mesocosm study of Phaeocystis globosa population dynamics-I. Regulatory role of viruses in bloom control. Harmful Algae 4: 859-874.

Brussaard CPD, Mari X, Van Bleijswijk JDL, Veldhuis MJW. (2005b). A mesocosm study of Phaeocystis globosa (Prymnesiophyceae) population dynamics II. 
Significance for the microbial community. Harmful Algae 4: 875-893.

Brussaard CPD, Martinez JM. (2008). Algal bloom viruses. Plant Viruses 2: 1-13.

Brussaard CPD, Payet JP, Winter C, Weinbauer M. (2010) Quantification of aquatic viruses by flow cytometryIn: Wilhelm SW, Weinbauer MG, Suttle CA(eds) Manual of Aquatic Viral Ecology. ASLO: Waco, TX, USA, pp 102-109.

Calquin P, Probert I, Lefebvre S, Veron B. (2008). Effects of temperature on photosynthetic parameters and TEP production in eight species of marine microalgae. Aquat Microb Ecol 51: 1-11.

Cottrell MT, Suttle CA. (1995). Dynamics of a lytic virus infecting the photosynthetic marine picoflagellate Micromonas pusilla. Limnol Oceanogr 40: 730-739.

Daufresne M, Lengfellner K, Sommer U. (2009). Global warming benefits the small in aquatic ecosystems. Proc Natl Acad Sci USA 106: 12788-12793.

de Wit R, Bouvier T. (2006). 'Everything is everwhere, but, the environment selects'; what did Baas Becking and Beijerinck really say? Environ Microbiol 8: 755-758.

Deser C, Blackmon ML. (1993). Surface climate variations over the North Atlantic ocean during winter: 19001989. J Clim 6: 1743-1753.

Doney SC, Ruckelshaus M, Duffy JE, Barry JP, Chan F, English CA et al. (2012). Climate change impacts on marine ecosystems. Ann Rev Mar Sci 4: 11-37.

Ducklow HW, Steinberg DK, Buesseler KO. (2001). Upper ocean carbon export and the biological pump. Oceanography 14: 50-58.

Edwards M, Richardson AJ. (2004). Impact of climate change on marine pelagic phenology and trophic mismatch. Nature 430: 881-884.

Evans C, Archer SD, Jacquet S, Wilson WH. (2003). Direct estimates of the contribution of viral lysis and microzooplankton grazing to the decline of a Micromonas spp. population. Aquat Microb Ecol 30: 207-219.

Evans C, Brussaard CPD. (2012). Viral lysis and microzooplankton grazing of phytoplankton throughout the Southern Ocean. Limnol Oceanogr 57: 1826-1837.

Field CB, Behrenfeld MJ, Randerson JT, Falkowski P. (1998). Primary production of the biosphere: integrating terrestrial and oceanic components. Science 281: 237-240.

Flombaum P, Gallegos JL, Gordillo RA, Rincon J, Zabala LL, Jiao $\mathrm{N}$ et al. (2013). Present and future global distributions of the marine cyanobacteria Prochlorococcus and Synechococcus. Proc Natl Acad Sci USA 110: 9824-9829.

Franks PJS. (2001). Phytoplankton blooms in a fluctuating environment: the roles of plankton response time scales and grazing. J Plankton Res 23: 1433-1441.

Fuhrman JA. (1999). Marine viruses and their biogeochemical and ecological effects. Nature 399: 541-548.

Fuhrman JA, Steele JA, Hewson I, Schwalbach MS, Brown MV, Green JL et al. (2008). A latitudinal diversity gradient in planktonic marine bacteria. Proc Natl Acad SCi USA 105: 7774-7778.

Furrer R, Nychka D, Sain S. (2012). fields: Tools for spatial data. R Package Version 6.1. http://CRAN. R-project.org/package $=$ fields .

Gobler CJ, Hutchins DA, Fisher NS, Cosper EM, Sanudo-Wilhelmy SA. (1997). Release and bioavailability of C, N, P, Se, and Fe following viral lysis of a marine chrysophyte. Limnol Oceanogr 42: 1492-1504.
Grasshoff K (1983). Determination of nitrate. In: Grasshoff K, Erhardt M, Kremeling K (eds) Methods of Seawater Analysis. Verlag Chemie: Weinheim, Germany, pp 143-150.

Gregg WW, Conkright ME, Ginoux P, O 'Reilly JE, Casey NW. (2003). Ocean primary production and climate: global decadal changes. Geophys Res Lett 30: 1809.

Haaber J, Middelboe M. (2009). Viral lysis of Phaeocystis pouchetii: implications for algal population dynamics and heterotrophic $\mathrm{C}, \mathrm{N}$ and $\mathrm{P}$ cycling. ISME $J$ 3: 430-441.

Helder W, de Vries RTP. (1979). An automatic phenolhypochlorite method for the determination of ammonia in sea and brackish water. Neth J Sea Res 13: 154-160.

Hilligsøe KM, Richardson K, Bendtsen J, Sorensen LL, Nielsen TG, Lyngsgaard MM. (2011). Linking phytoplankton community size composition with temperature, plankton food web structure and sea-air $\mathrm{CO}_{2}$ flux. Deep Sea Res Part I 58: 826-838.

Huisman J, van Oostveen P, Weissing FJ. (1999). Critical depth and critical turbulence: two different mechanisms for the development of phytoplankton blooms. Limnol Oceanogr 44: 1781-1787.

Huisman J, Sharples J, Stroom JM, Visser PM, Kardinaal WEA, Verspagen JMH et al. (2004). Changes in turbulent mixing shift competition for light between phytoplankton species. Ecology 85: 2960-2970.

Huisman J, Thi NNP, Karl DM, Sommeijer B. (2006). Reduced mixing generates oscillations and chaos in the oceanic deep chlorophyll maximum. Nature 439: $322-325$.

Irigoien X, Huisman J, Harris RP. (2004). Global biodiversity patterns of marine phytoplankton and zooplankton. Nature 429: 863-867.

Jackson GA. (1990). A model of the formation of marine algal flocs by physical coagulation processes. Deep Sea Res Part A 37: 1197-1211.

Jacquet $S$, Heldal $M$, Iglesias-Rodriguez $\mathrm{D}$, Larsen $\mathrm{A}$, Wilson W, Bratbak G. (2002). Flow cytometric analysis of an Emiliana huxleyi bloom terminated by viral infection. Aquat Microb Ecol 27: 111-124.

Jurado E, van der Woerd HJ, Dijkstra HA. (2012). Microstructure measurements along a quasi-meridional transect in the northeastern Atlantic Ocean. J Geophys Res 117.

Keller DP, Hood RR. (2011). Modeling the seasonal autochthonous sources of dissolved organic carbon and nitrogen in the upper Chesapeake Bay. Ecol Model 222: 1139-1162.

Keller DP, Hood RR. (2013). Comparative simulations of dissolved organic matter cycling in idealized oceanic, coastal, and estuarine surface waters. J Marine Syst 109: 109-128.

Kimmance SA, Wilson WH, Archer SD. (2007). Modified dilution technique to estimate viral versus grazing mortality of phytoplankton: limitations associated with method sensitivity in natural waters. Aquat Microb ECol 49: 207-222.

Kimmance SA, Brussaard CPD. (2010). Estimation of viralinduced phytoplankton mortality using the modified dilution method. In: Wilhelm SW, Weinbauer M, Suttle CA. (eds) Manual of Aquatic Viral Ecology. ASLC, pp 65-73.

Koroleff F. (1969). Direct determination of ammonia in natural waters as indophenol blue. Coun Meet int Coun Explor Sea. C.M.-ICES/C: 9. 
Levitus S, Antonov JI, Boyer TP, Stephens C. (2000). Warming of the world ocean. Science 287: 2225-2229.

Longhurst AR. (2007). Ecological Geography of the Sea. Academic Press: London, UK.

Maat DS, Crawfurd KJ, Timmermans KR, Brussaard CPD. (2014). Elevated partial $\mathrm{CO}_{2}$ pressure and phosphate limitation favor Micromonas pusilla through stimulated growth and reduced viral impact. Appl Environ Microb 80: 3119-3127.

Malits A, Weinbauer MG. (2009). Effect of turbulence and viruses on prokaryotic cell size, production and diversity. Aquat Microb Ecol 54: 243-254.

Mari X, Kerros ME, Weinbauer MG. (2007). Virus attachment to transparent exopolymeric particles along trophic gradients in the southwestern lagoon of New Caledonia. Appl Environ Microb 73: 5245-5252.

Marie D, Brussaard CPD, Thyrhaug R, Bratbak G, Vaulot D. (1999). Enumeration of marine viruses in culture and natural samples by flow cytometry. Appl Environ Microbiol 65: 45-52.

Marie D, Simon N, Vaulot D. (2005). Phytoplankton cell counting by flow cytometry. In: Andersen RA (ed). Algal Culturing Techniques. Elsevier Academic Press: Burlington, MA, pp 253-268.

Martiny JBH, Bohannan BJM, Brown JH, Colwell RK, Fuhrman JA, Green JL et al. (2006). Microbial biogeography: putting microorganisms on the map. Nat Rev Microbiol 4: 102-112.

Matteson AR, Loar SN, Pickmere S, DeBruyn JM, Ellwood MJ, Boyd PW et al. (2012). Production of viruses during a spring phytoplankton bloom in the South Pacific Ocean near of New Zealand. FEMS Microbiol Ecol 79: 709-719.

Matteson AR, Rowe JM, Ponsero AJ, Pimentel TM, Boyd PW, Wilhelm SW. (2013). High abundances of cyanomyoviruses in marine ecosystems demonstrate ecological relevance. FEMS Microbiol Ecol 84: 223-234.

Mitra A, Flynn KJ. (2005). Predator-prey interactions: is 'ecological stoichiometry' sufficient when good food goes bad? J Plankton Res 27: 393-399.

Moebus K. (1996). Marine bacteriophage reproduction under nutrient-limited growth of host bacteria. I. Investigations with six phage-host systems. Mar Ecol Prog Ser 144: 1-12.

Mojica KDA, Brussaard CPD. (2014). Factors affecting virus dynamics and microbial host-virus interactions in marine environments. FEMS Microbiol Ecol 89: 495-515.

Mojica KDA, Evans C, Brussaard CPD. (2014). Flow cytometric enumeration of marine viral populations at low abundances. Aquat Microb Ecol 71: 203-209.

Mojica KDA, van de Poll WH, Kehoe M, Huisman J, Timmermans KR, Buma AGJ et al. (2015). Phytoplankton community structure in relation to vertical stratification along a north-south gradient in the Northeast Atlantic Ocean. Limnol Oceanogr; doi: 10.1002/ lno.10113.

Mühling M, Fuller NJ, Millard A, Somerfield PJ, Marie D, Wilson WH et al. (2005). Genetic diversity of marine Synechococcus and co-occurring cyanophage communities: evidence for viral control of phytoplankton. Environ Microbiol 7: 499-508.

Murphy J, Riley JP. (1962). A modified single solution method for the determination of phosphate in natural waters. Anal Chim Acta 27: 31-36.
Nagasaki K, Yamaguchi M. (1998). Effect of temperature on the algicidal activity and the stability of HaV (Heterosigma akashiwo virus). Aquat Microb Ecol 15: 211-216.

Oksanen J, Blanchet FG, Kindt R, Legendre P, Minchin PR, O'Hara RB et al. (2013). vegan: Community ecology package. R Package Version 2.0-6. http://CRAN. R-project.org/package=vegan.

Ortega-Retuerta E, Duarte CM, Reche I. (2010). Significance of bacterial activity for the distribution and dynamics of transparent exopolymer particles in the Mediterranean Sea. Microb Ecol 59: 808-818.

Paul JH. (2008). Prophages in marine bacteria: dangerous molecular time bombs or the key to survival in the seas? ISME J 2: 579-589.

Polovina JJ, Howell EA, Abecassis M. (2008). Ocean's least productive waters are expanding. Geophys Res Lett 35: L03618.

$\mathrm{R}$ Development Core Team (2012). R: A Language and Environment for Statistical Computing. R Foundation for Statistical Computing: Vienna, Austria.

Revelle W. (2014), psych: Procedures for Psychological, Psychometric, and Personality Research. R Package Version 1.4.5. http://CRAN.R-project.org/package= psych.

Richardson AJ, Schoeman DS. (2004). Climate impact on plankton ecosystems in the Northeast Atlantic. Science 305: 1609-1612.

Sabine CL, Feely RA, Gruber N, Key RM, Lee K, Bullister JL et al. (2004). The oceanic sink for anthropogenic $\mathrm{CO}_{2}$. Science 305: 367-371.

Sarmiento JL, Hughes TMC, Stouffer RJ, Manabe S. (1998). Simulated response of the ocean carbon cycle to anthropogenic climate warming. Nature 393: 245-249.

Sarmiento JL. (2004). Response of ocean ecosystems to climate warming. Global Biogeochem Cycles 18: GB3003.

Scanlan DJ, West NJ. (2002). Molecular ecology of the marine cyanobacterial genera Prochlorococcus and Synechococcus. FEMS Microbiol Ecol 40: 1-12.

Schlitzer R. (2002). Interactive analysis and visualization of geoscience data with Ocean Data View. Comput Geosci 28: 1211-1218.

Siegel DA, Doney SC, Yoder JA. (2002). The North Atlantic spring phytoplankton bloom and Sverdrup's critical depth hypothesis. Science 296: 730-733.

Stevens C, Smith M, Ross A. (1999). SCAMP: measuring turbulence in estuaries, lakes, and coastal waters. NIWA Water Atmosphere 7: 20-21.

Suttle CA, Chan AM, Cottrell MT. (1990). Infection of phytoplankton by viruses and reduction of primary productivity. Nature 347: 467-469.

Suttle CA, Chan AM. (1993). Marine cyanophages infecting oceanic and coastal strains of Synechococcus: abundance, morphology, cross-infectivity and growth characteristics. Mar Ecol Prog Ser 92: 99-109.

Suttle CA, Chan AM. (1994). Dynamics and distribution of cyanophages and their effect on marine Synechococcus Spp. Appl Environ Microbiol 60: 3167-3174.

Suttle CA. (2007). Marine viruses - major players in the global ecosystem. Nat Rev 5: 801-812.

Sverdrup EU. (1953). On conditions for the vernal blooming of phytoplankton. J Cons Cons Int Explor Mer 18: 287-295.

Taylor JR, Ferrari R. (2011). Shutdown of turbulent convection as a new criterion for the onset of spring phytoplankton blooms. Limnol Oceanogr 56: 2293-2307. 
Thingstad TF, Våge S, Storesund JE, Sandaa R-A, Giske J. (2014). A theoretical analysis of how strain-specifc viruses can control microbial species diversity. Proc Natl Acad Sci USA 111: 7813-7818.

Toggweiler JR, Russell J. (2008). Ocean circulation in a warming climate. Nature 451: 286-288.

Tomaru Y, Tarutani K, Yamaguchi M, Nagasaki K. (2004). Quantitative and qualitative impacts of viral infection on a Heterosigma akashiwo (Raphidophyceae) bloom in Hiroshima Bay, Japan. Aquat Microb Ecol 34: 227-238.

Tsai AY, Gong GC, Sanders RW, Chiang KP, Huang JK, Chan YF. (2012). Viral lysis and nanoflagellate grazing as factors controlling diel variations of Synechococcus spp. summer abundance in coastal waters of Taiwan. Aquat Microb Ecol 66: 159-167.

van de Poll WH, Kulk G, Timmermans KR, Brussaard CPD, van der Woerd HJ, Kehoe MJ et al. (2013). Phytoplankton chlorophyll $a$ biomass, composition, and productivity along a temperature and stratification gradient in the northeast Atlantic Ocean. Biogeosciences 10: 4227-4240.

Van de Waal DB, Verschoor AM, Verspagen JMH, van Donk E, Huisman J. (2010). Climate-driven changes in the ecological stoichiometry of aquatic ecosystems. Front Ecol Environ 8: 145-152.

Van Etten JL, Burbank DE, Xia Y, Meints RH. (1983). Growth cycle of a virus, PBCV-1, that infects Chlorellalike algae. Virology 126: 117-125.
Wang K, Wommack KE, Chen F. (2011). Abundance and distribution of Synechococcus spp. and cyanophages in the Chesapeake Bay. Appl Environ Microb 77: 7459-7468.

Waterbury JB, Valois FW. (1993). Resistance to co-occurring phages enables marine Synechococcus communities to coexist with cyanophages abundant in seawater. Appl Environ Microb 59: 3393-3399.

Weitz JS, Wilhelm SW. (2012). Ocean viruses and their effects on microbial communities and biogeochemical cycles. F1000 Biol Rep 4: 17.

Wilhelm SW, Suttle CA. (1999). Viruses and nutrient cycles in the sea - viruses play critical roles in the structure and function of aquatic food webs. Bioscience 49: 781-788.

Wilson WH, Nicholas JF, Joint IR, Mann NH. (1999). Analysis of cyanophage diversity and population structure in a south-north transect of the Atlantic Ocean. Bull Inst Oceanogr Fish 19: 209-216.

Yang YH, Motegi C, Yokokawa T, Nagata T. (2010). Largescale distribution patterns of virioplankton in the upper ocean. Aquat Microb Ecol 60: 233-246.

Zuur A, Ieno EN, Walker N, Saveliev AA, Smith GM. (2009). Mixed Effects Models and Extensions in Ecology with R. Springer: New York, NY.

Zuur AF, Ieno EN, Elphick CS. (2010). A protocol for data exploration to avoid common statistical problems. Methods Ecol Evol 1: 3-14.

Supplementary Information accompanies this paper on The ISME Journal website (http://www.nature.com/ismej) 